\title{
An examination of John Fewster's role in the discovery of smallpox vaccination
}

\author{
${ }^{1} \mathrm{~L}$ Thurston, ${ }^{2} \mathrm{G}$ Williams \\ ${ }^{1}$ Principal House Officer in Psychiatry, Nambour General Hospital, Queensland, Australia; ${ }^{2}$ Emeritus Professor of Medicine and Senior \\ Research Fellow in Philosophy, Faculty of Medicine and Dentistry, University of Bristol, Bristol, UK
}

ABSTRACT Edward Jenner is recognised today as the father of vaccination but, as this paper explores, he was not the only Gloucestershire doctor to be linked to this discovery. John Fewster, a local surgeon and apothecary, is also said to have experimented with vaccination, many years before Jenner. This claim is made in a letter addressed to John Coakley Lettsom, written by John Player, a Quaker farmer. Player describes in detail Fewster's realisation that cowpox could be used to protect against smallpox. This letter is frequently cited but has not previously been subjected to critical analysis. We have identified several inconsistencies, including conflicting dates and a possible ulterior motive in that Player's son was to marry Fewster's daughter. We think it unlikely that Player, a devout Quaker, would have consciously fabricated evidence, but argue that the discrepancies in his account undermine the assumption that Fewster carried out vaccination experiments prior to Jenner.We also explore the assertion that Fewster presented a paper in 1765 on the subject of cowpox and its protective effect over smallpox. We conclude that, although there is no doubt that Fewster did pre-empt Jenner's discovery of vaccination, he did not realise the significance or importance of this momentous medical advance.

KEYWORDS cowpox, Edward Jenner, John Fewster, John Player, vaccination, variolation

DECLARATION OF INTERESTS No conflict of interests declared.
Correspondence to $L$ Thurston

4/93 Parkyn Parade

Mooloolaba

Queensland 4557

Australia

e-mail lydia.thurston@doctors.org.uk

\section{INTRODUCTION}

The discovery of vaccination by Edward Jenner (1749$1823)$ in 1796 is generally accepted across the world. However, it is clear that Jenner was not the first to think of inoculating with cowpox to protect against smallpox, or to conduct experiments to test this hypothesis. Benjamin Jesty (1736-1816), a dairy farmer from Yetminster, decided to test the countryside fable that acquiring cowpox could protect against smallpox. In 1774, 24 years before the publication of Jenner's findings, Jesty inoculated his wife and two children with cowpox pus and later had one of his sons variolated (inoculated with smallpox) to confirm its protective effect.'

It has also been suggested that John Fewster (17381824), a Gloucestershire surgeon and apothecary who ran a lucrative variolation practice, also inoculated healthy children with cowpox several months before Jenner's famous 1796 experiment with James Phipps. As Jenner knew Fewster, who was several years his senior, this raises questions about the assumption that Jenner conceived the idea of vaccination himself. Fewster's alleged involvement hinges on a previously unpublished letter which was discovered at the Royal Society of Medicine in London by George Peachey (1862-1935), a general practitioner and keen medical historian. ${ }^{2}$ This letter is contained in a volume of letters addressed to
John Coakley Lettsom (I744-18I5), and was written by John Player (1725-I808), a Gloucestershire farmer. ${ }^{3}$

Peachey wrote a paper containing detailed critical examination of Player's account of the discovery of vaccination, as well as newly discovered historical evidence regarding the relationship between Fewster and Player. We suggest that Player may have had an ulterior motive for overstating Fewster's role and that, ultimately, Fewster could not see the advantages of vaccination and therefore continued to practise and promote variolation.

\section{JOHN PLAYER}

John Player, a yeoman and active member of the Society of Friends (Quakers), was born in Stoke Gifford, Gloucestershire. He married Mary Millett in 1775 and, at the time of writing his letter to Lettsom in 1802, was living in the village of Tockington, north of Bristol. Player was well-read, well-connected and had fingers in many pies. ${ }^{4} \mathrm{He}$ was in contact with a number of well-known personalities of the day, including Peter Collinson, the acclaimed botanist, and John Coakley Lettsom, founder of the Medical Society of London. ${ }^{5}$ Player regarded himself as an amateur scientist and wrote to Lettsom several times on wide-ranging themes, including theories about the atmospheric causes of whooping cough ${ }^{6}$ as 
well as observations concerning potato growing, ergot and fossils. ${ }^{7}$

His most controversial surviving letter concerns the subject of vaccination against smallpox, and specifically the pioneering role which he claimed for John Fewster, a friend and senior medical colleague of Jenner's, who practised medicine, midwifery and surgery in the town of Thornbury, a few miles south of Jenner's home in Berkeley. In his letter, Player asserted that Fewster had discovered the link between cowpox and its protection against smallpox, over 30 years before Jenner, thereby challenging Jenner's claim to the discovery of vaccination. ${ }^{3}$

\section{JOHN FEWSTER, VARIOLATOR AND ENTREPRENEUR}

Part of Fewster's autobiography is documented in the Bristol Infirmary Biographical Memoirs. After completing his education at Bristol Grammar School, Fewster began his medical career with a seven-year apprenticeship under Edward Bridges, an apothecary at the Bristol Infirmary. Exploiting family connections to land the position (his aunt, Mrs Hughes, was the first matron at the Infirmary), he became a 'dressing pupil' to the surgeon John Page, and hence gained a foothold in a medical career. At the end of these seven years Fewster writes: '...[I] went to London in October $|76|$ and entered for three courses of anatomical lectures with DrWatson of St Thomas' and Guy's, with Dr Mackington [l studied] midwifery and [with] Dr Hugh...materia medica and practice of physic. On my return to Bristol, I took a house in the Old Market...was getting into good practice when, I was offered a Sergeantry of an Ensign of Commission by Colonel Berkeley in the South Gloucestershire Militia. I accepted the offer and continued with the regiment 'til the peace. Soon after I heard of an Institution at Thornbury, where I have lived ever since."

Shortly after arriving in Thornbury, Fewster formed a connection with the Sutton family. The Suttons were experts in the field of variolation; the process of inoculating a person with smallpox matter in order to confer immunity against the disease. Robert Sutton and his sons revolutionised the process by developing a safer and nearly painless method of inoculation.' They were entrepreneurial in advertising variolation as a service, including bed and board with the added incentive of 'tea, wine, fish and fowl' all for a monthly fee. ${ }^{10}$ Gradually, 'inoculation houses' started to appear across the country, many of them franchised to Sutton and his business partners, and employing Sutton's own secret treatment protocol.

In contrast to variolation, vaccination involved the inoculation of cowpox (an orthopoxvirus closely related to the variola virus that causes smallpox) into an individual with the aim of providing immunity to smallpox. Cowpox is generally a relatively benign disease in humans and, according to Joseph Adams it was 'a disease well-known to the dairy farmers in Gloucestershire." The idea of inoculating humans with animal matter was certainly controversial at the time, but it was also revolutionary. In $180 \mathrm{I}$, Jenner communicated his belief that vaccination would lead to the total annihilation of smallpox. ${ }^{12}$ At the time, this was wishful thinking, as vaccination had not yet begun to clear smallpox from significant tracts of land. However, Jenner's prediction was eventually realised 180 years later and smallpox remains the only human infection to have been exterminated by public health measures.

\section{THE HOUSE AT THE THIRTEENTH MILESTONE}

Having been trained in the Suttonian method, Fewster soon became an avid variolator and with the assistance of two other local doctors (Joseph Wallis and Hugh Groves) he opened a variolation house in the village of Buckover, two miles north of Thornbury. In Player's letter to Lettsom, this house is described as being large and near the thirteenth milestone on the road from Bristol to Gloucester. ${ }^{3}$ Confusingly, two thirteenth milestones still stand today in Buckover, where the old Gloucester Road divides for just over a mile (see Figure I). After extensive local research and the study of maps from that period, we conclude that it is most likely that the variolation house was a property called 'Lower Buckover Farm', still in existence.

According to Player, it was here that Fewster first came across the idea that cowpox could provide smallpox immunity. Two brothers named Creed were variolated in Buckover in 1763. Instead of developing the usual local inoculation sore and satellite smallpox blisters, one of the brothers did not show any visible response to the infection, even when he was variolated again a second and third time. Fewster and Wallis were apparently perplexed by this and asked him whether he had ever had smallpox before. He is reported to have replied: 'I tell you I ha'n't had the smallpox, nor the great pox nither, but I have had the cowpox.' Following this new discovery, Player reports that both Jenner and Fewster became more attentive to the subject, but that no further discussion about the preventative use of cowpox was made at this stage.

\section{THE CONVIVIO-MEDICAL SOCIETY}

Fewster was also an active member of the ConvivioMedical Society, a group of doctors who met once a month to discuss medical cases over a meal and drink. According to Player, Fewster co-founded the Society when he moved to Thornbury in 1763, and Joseph Wallis, Edward Jenner, and Daniel Ludlow were the initial members (although John Baron, Jenner's 


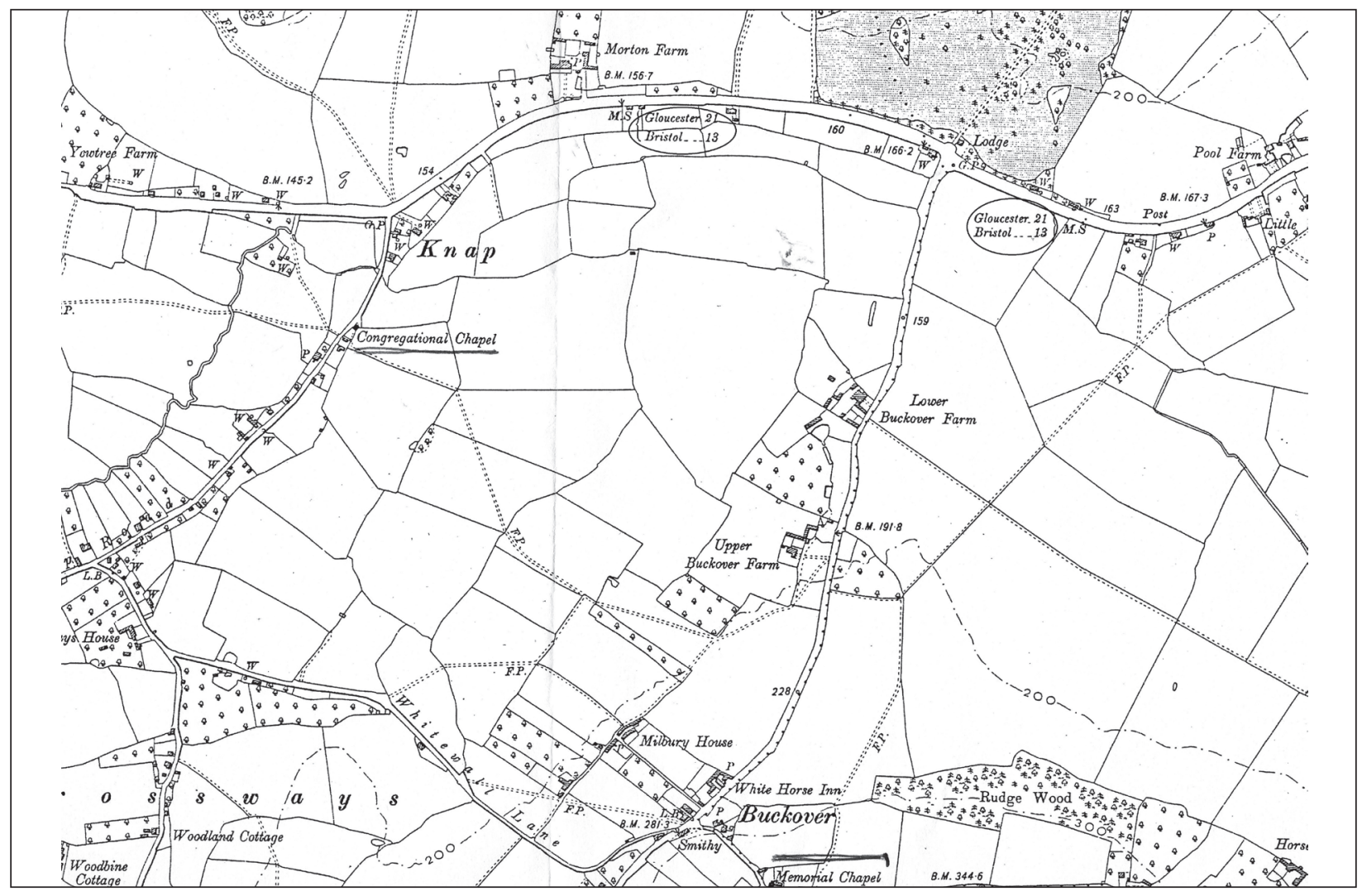

FIGURE I 1903 Ordnance Survey map of Thornbury, demonstrating the position of the two I3th milestones. Image reproduced with kind permission of Thornbury museum.

biographer, gives a different list of names of the members aside from Jenner). They used to meet at the Ship Inn in Alveston, near the tenth milestone from Bristol to Gloucester. Notably this was a different society from the Medico-Convivial society, of which Jenner was also a member, but which used to meet at the Fleece Inn in Rodborough, and whose meetings (as the name might suggest) were slightly more jovial. ${ }^{13}$

According to Player, this society met on the very night that Fewster had noted the Creed conundrum at Buckover, and it was brought up over their 'haunch of venison'. If this account is to be believed, Jenner would have been just 14 years old and at the start of his medical apprenticeship with Daniel Ludlow. Apart from Player's account, there is no evidence that Jenner was definitely present at this meeting, and it may have been unusual for a junior apprentice to be invited to a professional dinner for more senior doctors. Following this discovery at Buckover, Player writes: 'From this time Fewster and Jenner became more attentive to the circumstance, as did Wallis, but the discovery thus made lay dormant for several years, during which period Wallis died and Jenner obtained a diploma as Doctor of Medicine which consequently took him from manual practice... so that the discovery of the power of the cowpocks rested pretty much with Fewster.'3
Significantly, this account is radically different from the story promulgated by Baron, in which a young Jenner is told by a milkmaid from Chipping Sodbury of the folk belief that people who have had cowpox could not catch smallpox..$^{13}$

\section{JOHN FEWSTER: EXPERIMENTS WITH VACCINATION?}

Following this discussion, the subject apparently lay dormant, and it was not until many years later that Player claims he revisited this subject with Fewster. In March 1796, Fewster visited Player's house to attend to his eldest son who was unwell with a fever. During this visit they discussed the subject of cowpox and its possible protective effect against smallpox. Player writes: '...the idea had struck his [Fewster's] mind forcibly, but he had not as yet ventured on the experiments, and [he] further said [that] he had spoken to Dr Jenner years ago on the subject but nothing had yet been done.'

Not long after this conversation, Player maintained, it came to his attention that Fewster had 'given the cowpock by inoculation from a cow to three children of the Hodges family in Thornbury'. Player states that Fewster's successful trial spurred him on to vaccinate a large number of poor children in the village of Tockington, under the patronage of a local philanthropic gentlewoman. ${ }^{3}$ 


\section{FEWSTER'S SIDE OF THE STORY}

Fewster's letter to a Mr Rolph (a former Thornbury surgeon, who had moved to Peckham) remains our only verbatim account of his brush with early vaccination. Unfortunately, the original copy of this letter cannot be found, and it is only abstracted in George Pearson's An Inquiry Concerning the History of the Cowpox. ${ }^{14}$ George Pearson was a successful physician and scientist who became envious of Jenner and his increasing fame, and tried to rob him of any financial credit for his discovery by proclaiming himself as the leading 'cowpox inoculator' in London. He established the Vaccine-Pock institution and insultingly offered Jenner a role as a 'corresponding physician', which he politely refused..$^{15}$ Pearson testified against Jenner during the House of Commons investigation in 1802. He used Benjamin Jesty as ammunition against Jenner's case, and tried to demolish his reputation further by proving that Jesty's experiment had come first - as indeed it had. ${ }^{16}$ However, Jesty's experiments had led nowhere and had not been publicised, and there is no evidence that Jenner had heard of them. Given Pearson's concerted attempts to undermine Jenner it is difficult to trust his abstracted account of Fewster's alleged letter to Rolph.

According to Pearson, Fewster's letter stated: 'In the spring of 1768 I came to live at Thornbury...the late $\mathrm{Mr}$ Grove and myself formed a connection with Mr Sutton, the celebrated inoculator, and to inoculate for the smallpox, we took a house at Buckover. We found in this practice that a great number of patients could not be infected with the smallpox poison...on inquiry [we] found that all those who were uninfectable had undergone the cowpox. I communicated this fact to a medical society of which I was then a member, and ever afterwards paid particular attention to determine the fact. I can now with truth affirm that I have not been able to produce the smallpox in a single instance among persons who have had the true cowpox...I have since that inoculated near 2000 for the smallpox amongst whom there were a great number who had gone through the cowpox; the exact number of these I cannot tell, but I know that they all resisted the infection of variolous matter.'14

Fewster concludes his letter with his belief that cowpox is a more severe disease than inoculated smallpox, and that he does not see any great advantage from inoculation with cowpox; '...inoculation for the smallpox seems to be so well understood that there is very little need for a substitute. It is curious, however, and may lead to other improvements.' ${ }^{\prime 4}$

Baron gives a shortened account of Fewster's letter to Rolph, taken from Pearson's abstract, focusing mainly on Fewster's conclusion that he does not see any great advantage in inoculating with cowpox. In a bid to preserve Jenner's reputation, he belittles Fewster's claim, by leaving out the information about the house at Buckover, and the Creed 'experiment'. Baron talks about Jenner's membership to the Convivio-Medical Society in Alveston and writes about cowpox: 'Dr Jenner has frequently told me that at the meetings of this society he was accustomed to bring forward the reported prophylactic virtues of cowpox, and earnestly recommend his medical friends to prosecute the inquiry. All his efforts were, however, ineffectual; his brethren were acquainted with the rumour, but they looked upon it as one of those vague notions from which no accurate or valuable information could be gathered...He (Jenner) often recurred to the subject in these meetings; at length it became so distasteful to his companions, that I have many times heard him declare that they threatened to expel him if he continued to harass with so unprofitable a subject.'13

Baron claims that there were further letters in existence between the two gentlemen in which Fewster assigns all merit in vaccination discovery to Jenner. Interestingly, text from these letters is not cited by Baron; who seems to want to stamp out any claim that Fewster may have to the discovery of vaccination. ${ }^{16}$

\section{CONFLICTING INFORMATION}

If Player's account is true, Fewster not only planted the notion of vaccination in Jenner's mind, but also beat him to it on the experimental front. There are, however, a few points in Player's memoirs which raise doubts about this interpretation.

There is the matter of conflicting dates regarding Fewster's move to Thornbury. In Fewster's brief autobiography, he states that he moved to Thornbury 'soon after the peace'. ' 'The peace' which he refers to is the end of the Seven Years War, which concluded in 1763. This date would agree with Player's account of the Creed brothers attending the variolation house at Buckover in 1763. However, in the letter addressed to $\mathrm{Mr}$ Rolph, Fewster is supposed to have moved to Thornbury in the spring of $1768 .{ }^{14}$ If Fewster did move to Thornbury in 1768, then he could not possibly have made the discovery at Buckover in 1763. As the original letter cannot be found it is not possible for us to rule out a mistranscription of this date in Pearson's Inquiry, made more likely by the fact that Fewster also mentions the discovery he made at Buckover in this letter to Rolph. Additionally, if 1768 is the correct year of Fewster's move to Thornbury, it does not account for the five years which elapsed following the end of the Seven Years War in 1763.

\section{THE RUMOUR OF A PAPER}

Strangely, Fewster does not appear to have written or 
published any articles on vaccination. Many books contain the claim that Fewster was the author of a paper entitled Cowpox and its inability to prevent smallpox which he supposedly presented to the Medical Society of London in 1765. ${ }^{17}$ This could not have happened as the Medical Society of London was not founded until I773, by none other than Dr Lettsom. The Medical Register of I 783 does, however, provide some information about another, smaller, medical society which was in existence in London prior to this one. This society was simply called 'The Medical Society' and was founded in 1752. However, no paper by Fewster appears in any of the volumes published by this society. ${ }^{18}$

It is worth noting that neither Fewster nor Player mention such a paper. The furthest we have managed to trace this claim back is to 1886 when Ferdinand Hebra writes:'.... in 1765 Sutton and Fewster gave a description of the cow-pox, and drew attention to its protective power against smallpox.' ${ }^{\prime 9}$ However, the true origin of this paper and its existence still remains a mystery. We suggest that it was merely a rumour, based on misreporting Fewster's claim that he communicated his discovery at Buckover to: '... a medical society of which I was then a member...', referring to the ConvivioMedical Society in Alveston. ${ }^{14}$

\section{FAMILY TIES}

During our research it came to our attention that the Player and Fewster families were linked together in more ways than one. At the time of writing his letter to Lettsom, Fewster was merely Player's family doctor, but within two years their families were connected by marriage. In June 1804 Fewster's daughter Elizabeth married Player's son, John. ${ }^{20}$ This raises the possibility that Player had an ulterior motive in enhancing Fewster's reputation by promoting him as the discoverer of vaccination - and by making the case to Lettsom, one of the most influential physicians of the day.

However, Player's religious background may stand in his favour. We know that John Player was a dedicated and faithful Quaker from reading his diaries, which are currently in the possession of a living descendant, Madeleine Wright." ${ }^{21}$ The diaries reveal aspects of Player's everyday life, including his many contributions to the Society of Friends. By contrast, Fewster's family were not Quakers. It is unlikely that Player would have celebrated the fact that his son was discontinuing his faith by his marriage to Elizabeth; 'marrying-out' of the Quaker faith usually resulted in disownment from the faith as it was seen as a sin to be married in front of a priest. ${ }^{22}$

A pious Quaker would not attempt to bring fame upon himself or indeed others, nor would it be in their nature to lie - especially to such an esteemed Friend as Lettsom. If Player adhered to these conventions, then his account of Fewster might merely be another of his interesting observations, similar to his description on the causes of whooping cough, which he wished to pass on to his fellow Quaker, rather than propaganda designed to push Fewster into prominence.

\section{THE FARMER'S HYPOTHESES}

There are two crucial paragraphs of the letter, which Peachey inexplicably failed to include in his paper of 1929. The first (Appendix A) was a paragraph relating to Fewster's vaccination of the Hodge's children. In this extract, Player describes the process of 'arm to arm propagation', a procedure which involves successive inoculation with strains of the same original cowpox matter, and was a term and theory which was thought to be first coined by Jenner in his Inquiry. Player suggests that Fewster practised this procedure prior to Jenner, and that it was therefore not Jenner's original discovery.

The second paragraph (Appendix B), contained information relating to an in-depth description of 'The Scratches and Greses'. This refers to a condition at the time known as 'Grease', a pox-like disease occurring in horses. Jenner hypothesised that grease was the origin of cowpox, and that it was transferred to cows that were milked by stable-boys. This was a theory which was greatly criticised by Jenner's opponents. ${ }^{16}$ The hypothesis was again unique to Jenner's Inquiry, but Player describes it in detail in his letter to Lettsom. Does this mean that this theory actually derived from another country folktale, and was not unique to Jenner? Player does not openly malign Jenner in his letter, but the mere mention of what were thought to be theories unique to Jenner, suggests that he is trying to contest his claim to the discovery of smallpox vaccination by implying a lack of scientific integrity.

\section{CONCLUSIONS}

Since Peachey's examination of Player's letter to Lettsom in 1929, we have uncovered hitherto unknown information which has helped us to explore Player's character and his relationship with Fewster more thoroughly. Perhaps the most important discovery that we have made is that of Player's son marrying Fewster's daughter, and the exploration of the ulterior motive that this may have provided Player with for writing his letter. The discovery of the two further paragraphs mentioning 'arm to arm propagation' and 'grease', suggest that either Player was trying to undermine Jenner in order to strengthen Fewster's claim, or that Jenner's theories were lacking originality.

Player's account does contain some intriguing discrepancies. The chief discrepancy remains the date of Fewster's move to Thornbury. Of course, one explanation for this inconsistency could be that Player simply 
misremembered the date, given that he was writing his letter almost 40 years later, and apparently without the knowledge or assistance of Fewster.

Due to the inconsistencies in Player's account, and the lack of evidence in favour of his version of events, it cannot be proved that Fewster carried out vaccination experiments before Jenner. However, there is no denying that Fewster did recognise the link between cowpox and smallpox immunity while working at the inoculation house in Buckover, and that the 'discovery' of vaccination actually developed from the practice of variolation. Fewster may even have planted the seed of thought in the young Jenner's mind when conveying his discovery that Creed had not reacted to variolation to his colleagues at the Convivio-Medical Society. If so, the conventional account of Jenner's encounter with the milkmaid, which is ultimately attributable to Baron, might be a smokescreen designed to divert attention from Fewster's role and the possibility that Jenner was not the original thinker that Baron (Jenner's mentee and selfprofessed admirer) claimed him to be. ${ }^{16}$

As a strong supporter of the Suttons, and one whose income was assured by variolation, Fewster may not have realised the significance of his discovery or wished to detract from variolation. He might not have seen the need to conduct formal experiments. Perhaps he also felt that a publication under his name would not hold any weight and would not be recognised. If he truly presented a paper on the subject in 1765 it is possible that this was met with opposition and perhaps dissuaded him from pursuing his line of enquiry any further.

It was ultimately Jenner who not only recognised the significance of this discovery, but also went on to experiment and develop a new form of immunisation which was safer than smallpox inoculation, and to force his discovery into mainstream medical practice. Without Jenner, the fight against smallpox and its eventual extermination would not have started at the turn of the 19th century.As Jean de Carro (1802) put it so eloquently: '...Tout le monde avoit vu tomber des pommes d'un arbre, et balancer une lampe suspendue aux voûtes d'une église, avant Newton et Galileo!' (Everyone had seen apples falling from a tree, and a lamp swinging from the vaults of a church before Newton and Galileo!). ${ }^{23}$

\section{ACKNOWLEDGMENTS}

We would like to thank the staff at the Thornbury Museum, in particular Sandi Shallcross, and the Gloucestershire Records Office for their help; Madeleine Wright of Port Eynon, South Wales for generously providing insight into John Player's diaries; Dr Nicholas Cambridge, for his advice regarding I8th century medical societies; and $\mathrm{Dr}$ Arthur Boylston for much useful discussion during the preparation of the paper.

\section{Appendix A}

'From my inquiry of J. Fewster he has informed me that he have from the Children of Hodges that were from the Icor taken from a Cow inoculated in succession to the present time as it have in graduation passed through various(e) subjects and that it is as effectual now as when taken from the child of Hodges. ${ }^{3}$

\section{Appendix B}

"I have said in this account "The Scratches or Greses". It may be altogether improper to give a short explanation to this duplicity of names, Scratches is a disease frequently attacking Horses which are kept in the stable on dry food, its appearance is a small swelling about the fetlock joint, of one or both hind legs, from which swelling issues a moisture, that first appears like sweat on the hair and in a few drops after, a thin Icor is discharged under the Hock joint, in the hollow part below it and the heel. This if the animal is high in flesh and have but little exercise, and no medical aid given, soon becomes more extensive, by issuing from above the joint, as well as below, and discharging a thick matter which is now become the Greses. If at all it is in its first stage, that infection can be given to the Cows but this may soon be determined by experiment from which no ill effect can ensue, and I think an experiment well worthy trying, not barely from the Horse to the Cows but from the Horse to the human body.3 


\section{REFERENCES}

I Pead. PJ. Benjamin Jesty. Dorset's Vaccination Pioneer. Chichester: Timefile Books; 2009.

2 Peachey GC. John Fewster, an unpublished chapter in the history of vaccination. Annals of Medical History 1929; I: 229-40

3 Player ]. Narrative [sic] of the discovery of the cowpock as preservative from...the smallpox, compiled from the cranium portfolio of Ruricola Glocestris. From a volume of letters addressed to Dr John Coakley Lettsom, kept at the Royal Society of Medicine. MSS.234. London; 1802

4 John Player of Stoke Gifford. Player Family of South Gloucestershire. Gloucestershire Archives, Gloucestershire Records Office. D5090// 8

5 Hunting, P.The Medical Society of London. Postgrad Med J 2004; 80: 350-4.

6 Player J. On the chin, or whooping cough. From a volume of letters addressed to Dr John Coakley Lettsom, kept at the Royal Society of Medicine. MSS.234(4). London; I802

7 Player J. Hints to Horticulturalists, agriculturalists and naturalists... with some means...to remedy several diseases [by] Ruricola Glocestris. From a volume of letters addressed to Dr. John Coakley Lettsom, kept at the Royal Society of Medicine. MSS.234 (3). London; I 802

8 Smith. R. Biographical Memoirs Volume 2. Bristol Royal Infirmary Richard Smith Papers. Bristol Records Office. 35893/36/b i. I7351777.

9 Boylston A. Daniel Sutton, a forgotten I8th century clinician scientist. J R Soc Med 20I2; 105: 85-7. http://dx.doi.org/I0.I258/ irsm.2012.12k00I

10 Ipswich Journal, 16 April 1757. Repeated 14 and 2 I May.
II Adams J. Observations on Morbid Poisons, Phagedaena, and Cancer. London: J. Johnson; I795. p.I56.

12 Jenner E. On the Origin of the Vaccine Innoculation. London: G.S Elsick; I863. p.8.

I3 Baron J. The Life of Edward Jenner, M.D. L.L.D., F.R.S., Physician Extraordinary to the King, \&c. \&c with illustrations of his doctrines and selections from his correspondence. London: Henry Colburn; 1827. p. 45-50; | $2 \mid-2$.

14 Pearson G. An Inquiry Concerning the History of The Cowpox, principally with $a$ view to supersede and extinguish the Smallpox. London: J. Johnson; I798. p. I02-4.

15 Williams G. Angel of Death. The Story of Smallpox. Chippenham and Eastbourne: CPI Antony Rowe; 20I0. p.203-5.

16 Boylston $A$. The origins of vaccination: no inoculation, no vaccination. I $R$ Soc Med 2013; 106: 395-8. http://dx.doi. org/I0.II77/0I4I0768I3499293

17 Dixon CW. Smallpox. London: J\&A Churchill; 1962. p.250.

18 The Medical Register for the year I783. London: Joseph Johnson; 1783. p.38.

19 Hebra F. On Diseases of the Skin including Exanthemata. Volume I. London:The New Sydenham Society; I866. p.27I.

20 Provincial Occurrences with all the Marriages and Deaths. Monthly Magazine; or British Register; 1804; 18: 83.

21 Wright M, Port Eynon, South Wales (personal communication).

22 Skidmore G. Elizabeth Fry:A Quaker Life: Selected Letters and Writings. Oxford:AltaMira Press; 2005. p.7.

23 De Carro J. Observations et Expériences sur la vaccination. Vienna: Joseph Geisstinger; 1802. p.20 